\title{
Radio-isotope investigations in primary myeloid metaplasia
}

\author{
A. J. BOWDLER \\ From the Medical Unit, University College Hospital Medical School, London
}

SYNOPSIS Chromium-51 and iron-59 studies in patients with primary myeloid metaplasia show that the anaemia of the condition is dependent on depression of marrow activity, aggravated in about one-third of cases by accelerated red cell destruction to which the marrow compensatory response is inadequate. Surface measurements of isotope activity assist in assessing dependence on extramedullary sites for erythropoiesis and in diagnosis. The relevance of these findings to the hypotheses of the pathogenesis of the condition is discussed.

The conditions which comprise the group known as the 'myeloproliferative disorders' are characterized by quantitative and qualitative abnormalities in the proliferation of haemopoietic cells for which no demonstrable cause is evident (Dameshek, 1951). It is not known at present whether any common aetiological factor unites the group: the essential basis for their being classified together lies in the abnormal proliferative tendency which extends to cells, such as the fibroblast and reticulum cell, which do not enter the peripheral blood. The various conditions differ not only in the combinations of cell-lines involved but in the degree of maturation of the most prominent cells affected, so that both acute and chronic forms of disorder may be distinguished.

The classical types of chronic myeloproliferative disease consist of polycythaemia vera, chronic myeloid leukaemia, essential thrombocythaemia, and primary myeloid metaplasia, while the acute forms include acute myeloblastic leukaemia, acute myeloid metaplasia, and the variants of the $\mathrm{Di}$ Guglielmo syndrome. As was strongly emphasized by Hutt, Pinniger, and Wetherley-Mein (1953), combinations of features frequently occur which overlap the conventional descriptions of these conditions, and the wide spectrum of clinico-pathological patterns includes many cases which lie between these categories. It is an essential part, however, of the study of disease to distinguish groups of cases showing common features, and to determine the significance of such groupings in terms of sequelae, prognosis, and pathological correlations. To be most useful, the criteria must be carefully selected,

Received for publication 30 March 1961. and difficulties have arisen from an undue emphasis on the peripheral blood findings in these diseases, since these may change radically during the course of a single case.

The development of satisfactory biopsy techniques has made histological criteria more useful clinically, and by such evidence it has proved possible to distinguish one such group of cases showing haemopoietic tissue in sites other than the bone marrow, especially in the spleen, and to a lesser extent also in the liver. Excluded from consideration are those which have predominantly blast-cell proliferation, the rare cases in which localized heterotopic marrow is found in isolation in sites such as the adrenal (Collins, 1932), and those in which extramedullary erythropoiesis is clearly compensatory to an anaemia of known origin. A confusing variety of names, summarized by Heller, Lewisohn, and Palin (1947), has been given to cases falling into this group, including myelosclerosis, megakaryocytic myelosis, aleukaemic myelosis, and panmyelosis. The broader term 'primary myeloid metaplasia' embraces all such cases regardless of the dominance of one or other cell-line, or the presence of variable features such as marrow fibrosis. It was introduced by Block and Jacobson (1950) following the use of 'agnogenic myeloid metaplasia of the spleen' by Jackson, Parker, and Lemon (1940) and Reich and Rumsey (1942), and the usage here differs only in not excluding cases which have a phase of polycythaemia.

The findings most commonly associated with myeloid metaplasia are a chronic anaemia of insidious onset, splenomegaly, a less prominent hepatomegaly, leucoerythroblastosis, and progressive fibrosis of the bone marrow. The haematological 
findings are variable and may include anaemia, polycythaemia, leucocytosis, leucopenia, thrombocytopenia, and thrombocythaemia. An account of the various clinical patterns of this condition has been given elsewhere (Bowdler and Prankerd, 1961). The predominant feature may be bone marrow failure with splenomegaly, polycythaemia, leucocytosis, thrombocythaemia or megakaryocytosis, or haemolytic anaemia, but the pattern may vary with time and the features become superimposed. Assessment of such cases may be difficult, especially when accelerated red cell destruction is present with marrow failure, and it was the purpose of this study to clarify aspects of red cell production and destruction in this condition by means of radio-isotope techniques, as has been done in chronic renal failure by Joske, McAlister, and Prankerd (1956) and by Bailey and Prankerd (1958) in thalassaemia.

\section{METHODS}

Chromium-51 labelled red cells and iron-59 tagged plasma were employed by combining the techniques described by Joske et al. (1956) and Harris, McAlister, Prankerd, and Singh (1957). A sample of the patient's red cells was labelled with $50 \mu \mathrm{c}$. of chromium-51 (as sodium chromate) and recombined with an approximately equal quantity of plasma treated with $5 \mu \mathrm{c}$. of iron-59, using ferric chloride of high specific activity. A small sample was set aside for later determination of activity by well counting and the remainder was injected intravenously into the patient after its activity in the syringe had been determined at a standard distance from the collimated scintillation counter used for the surface counting. The subsequent surface counts made over the lumbar spine, sternum, spleen, liver, and thigh at approximately daily intervals were expressed in fractions of the activity of the syringe count. By reason of the difference between the energies of the $\gamma$-radiations of the two isotopes, these could be assessed separately by the use of suitable selected settings of the discriminator bias. At the time of the successive surface counts, further blood samples were taken and their activity measured at the end of the investigation in a well counter.

From the results, the red cell life, iron utilization, and patterns of surface activity of the isotopes over the organs studied were calculated. Marrow activity was assessed by means of indices as described in the text. Methods of $\#$ estimating erythropoietic activity which depend on the disappearance of iron-59 from the plasma have not been . used in this study since they are open to theoretical objections in the presence of impaired iron utilization (Joske et al., 1956) and have been shown to correlate $\vec{?}$ poorly with other evidence of depressed red cell production by Nathan and Berlin (1959) in their cases of $\vec{A}$ myeloid metaplasia.

In the course of the investigation it was found necessary if to derive an expression for the iron-59 activity of an $\mathrm{G}$

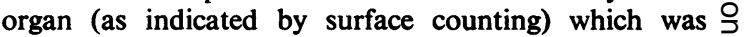
arising from the blood within the organ and to distinguish this from the activity of isotope held in the tissues. This $Z$ was possible where there was no accumulation of chromium-51 in the tissue or where this was negligible, by estimating the surface counts expected from the relative values of the activities of the two isotopes in the blood. The method is shown in detail in the Appendix.

\section{CASES}

Fourteen patients were investigated, three men and 11 women, between the ages of 26 and 74 years. The diagnosis rested on histological proof in 12 and details of these cases were included in the series described elsewhere (Bowdler and Prankerd, 1961). In the remaining two cases biopsy was not justified but the diagnosis was considered established on other grounds. In 13 cases a combined isotope investigation was made but in one only a chromium-51 study was performed. Details of the patients at the time of the investigation and a summary of the results are given in the Table. Eleven of the 14 patient had haemoglobin levels below $12.8 \mathrm{~g}$. \%.

TABLE

SUMMARY OF CLINICAL FEATURES AND RESULTS

\begin{tabular}{|c|c|c|c|c|c|c|c|c|c|c|c|c|}
\hline \multirow[t]{2}{*}{ Case } & \multirow[t]{2}{*}{ Sex } & \multirow[t]{2}{*}{ Age } & \multirow[t]{2}{*}{$\begin{array}{l}H b \\
(\mathrm{~g} . \%)\end{array}$} & \multirow[t]{2}{*}{$\begin{array}{l}\text { WBC } \\
\left(\text { per mm } m^{3}\right)\end{array}$} & \multirow{2}{*}{$\begin{array}{l}\text { Spleen } \\
\text { Size } \\
(\mathrm{cm} .)\end{array}$} & \multirow[t]{2}{*}{$\begin{array}{l}T \frac{1}{2} C r \\
\text { (days) }\end{array}$} & \multirow{2}{*}{$\begin{array}{l}\text { Iron } \\
\text { Utilized } \\
(\%)\end{array}$} & \multirow[t]{2}{*}{$\begin{array}{l}T \frac{1}{2} F e \\
\text { (days) }\end{array}$} & \multirow[t]{2}{*}{$\begin{array}{l}\text { Marrow } \\
\text { Index }\end{array}$} & \multirow{2}{*}{$\begin{array}{l}\text { Index of } \\
\text { Marrow } \\
\text { Activity }\end{array}$} & \multicolumn{2}{|c|}{$\begin{array}{l}\text { Iron-59 Surface } \\
\text { Curves }\end{array}$} \\
\hline & & & & & & & & & & & Marrow & Spleen \\
\hline $\begin{array}{l}1(1 \mathrm{~B})^{1} \\
2(1 \mathrm{E}) \\
3(2 \mathrm{~A}) \\
4(2 \mathrm{~B}) \\
5(4 \mathrm{~A}) \\
6(1 \mathrm{~A}) \\
7 \\
8 \\
9(5 \mathrm{~A}) \\
10(5 \mathrm{C}) \\
11(1 \mathrm{E}) \\
12(3 \mathrm{~A}) \\
13(4 \mathrm{C}) \\
14(5 \mathrm{~B})\end{array}$ & $\begin{array}{l}\mathbf{M} \\
\mathbf{M} \\
\mathbf{F} \\
\mathbf{F} \\
\mathbf{F} \\
\mathbf{M} \\
\mathbf{F} \\
\mathbf{F} \\
\mathbf{F} \\
\mathbf{F} \\
\mathbf{F} \\
\mathbf{F} \\
\mathbf{F} \\
\mathbf{F}\end{array}$ & $\begin{array}{l}61 \\
64 \\
64 \\
75 \\
75 \\
54 \\
63 \\
74 \\
66 \\
72 \\
55 \\
62 \\
26 \\
50\end{array}$ & $\begin{array}{r}9 \cdot 1 \\
12 \cdot 6 \\
16.4 \\
12.5 \\
14.5 \\
6.6 \\
10 \cdot 2 \\
11.0 \\
3.6 \\
11.1 \\
12.0 \\
11.0 \\
14.7 \\
3.4\end{array}$ & $\begin{array}{r}1,400 \\
11,200 \\
9,600 \\
24,000 \\
11,600 \\
3,950 \\
4,200 \\
5,000 \\
1,400 \\
21,000 \\
2,600 \\
25,500 \\
13,500 \\
6,200\end{array}$ & $\begin{array}{c}6 \\
3 \\
3 \\
12 \\
9 \\
3 \\
14 \\
10 \\
\text { RIF } \\
14 \\
12 \\
14 \\
6 \\
12\end{array}$ & $\begin{array}{l}26 \\
17 \frac{1}{2} \\
26 \\
26 \\
24 \\
26 \\
26 \\
20 \\
6 \\
17 \\
24 \\
24 \\
24 \\
14\end{array}$ & $\begin{array}{l}70 \\
71 \\
75 \\
50 \\
65 \\
34 \\
59 \\
77 \\
66 \\
64 \\
75 \\
70 \\
90 \\
\end{array}$ & $\begin{array}{l}3 \cdot 7 \\
1.5 \\
3.0 \\
2 \cdot 6 \\
2.7 \\
1 \cdot 8 \\
2 \cdot 3 \\
2 \cdot 3 \\
2 \cdot 4 \\
2.5 \\
3 \cdot 1 \\
3.0 \\
3 \cdot 2 \\
-\end{array}$ & $\begin{array}{l}19 \\
47 \\
25 \\
19 \\
24 \\
19 \\
26 \\
33 \\
28 \\
26 \\
24 \\
23 \\
31 \\
\end{array}$ & $\begin{array}{l}0.6 \\
2.21 \\
1 \cdot 15 \\
0.85 \\
0.95 \\
0.45 \\
0.68 \\
1.54 \\
2.63 \\
1.85 \\
0.80 \\
0.74 \\
0.95 \\
0.85\end{array}$ & $\begin{array}{l}\text { Low } \\
\text { None } \\
\text { Low } \\
\text { Low } \\
\text { Normal } \\
\text { None } \\
\text { None } \\
\text { Low } \\
\text { Low } \\
\text { Low } \\
\text { Low } \\
\text { None } \\
\text { Low } \\
\text { - }\end{array}$ & $\begin{array}{l}\text { Type 1 } \\
\text { Type 1 } \\
\text { Type 1 } \\
\text { Type 1 } \\
\text { Type 1 } \\
\text { Type 2 } \\
\text { Type 2 } \\
\text { Type 2 } \\
\text { Type 2 } \\
\text { Type 3 } \\
\text { Type 3 } \\
\text { Type 3 } \\
\text { Type 3 } \\
-\end{array}$ \\
\hline
\end{tabular}

${ }^{1}$ The case numbers in brackets relate to the clinical descriptions given by Bowdler and Prankerd (1961). This table gives the findings at the time of the isotope investigation 
RESULTS

RED CELL SURVIVAL The orthodox method for the determination of red cell survival by the chromium-51 method was used, the results being expressed as the time for $50 \%$ of the chromium activity to disappear from the blood $\left(=\mathrm{T} \frac{1}{2} \mathrm{Cr}\right)$. Normal values in this unit lie between 24 and 28 days. In nine cases survival was at or close to the normal value, and in five cases significantly reduced survival times were recorded, the $\mathrm{T} \frac{1}{2} \mathrm{Cr}$ in these being $20,17 \cdot 5,17,14$, and six days respectively. Case 1 had a normal red cell survival on first being investigated but three years later he had become severely anaemic and was requiring frequent blood transfusions. At this time, the $\mathrm{T} \frac{1}{2} \mathrm{Cr}$ had fallen to nine days.

In Case 2, in which the $\mathrm{T} \frac{1}{2} \mathrm{Cr}$ of the patient's own cells was 17.5 days, a second study was made using fresh, normal, compatible donor blood. The donor red cell survival was not significantly different from that of the patient's cells ( $\mathrm{T} \frac{1}{2} \mathrm{Cr} 17.7$ days). In this subject, the only significant source of red cells detectable was the spleen. It was concluded that the haemolysis was not due to an intracorpuscular defect, and that spleen-derived red cells responded to the destructive agent to the same extent as normal cells originating from the marrow.

Surface counting over the spleen and liver for chromium-51 activity was used to assess the role of these organs in the destruction of red cells. The three cases with least reduction in red cell life showed no significant uptake of the isotope by these organs but in Cases 9 and 14 there was a distinct rise in the spleen-precordium ratio for chromium-51, with a lesser rise in the liver-precordium ratio. A similar pattern was found in Case 1 when the red cell life was reduced. In no case was the spleen involved alone.

IRON UTILIZATION Iron utilization is calculated as the product of the iron-59 activity of unit volume of red cells and the total red cell volume, which is obtained from the dilution of the chromium-51 labelled cells. The iron utilized on successive days is plotted as the 'iron utilization curve' (Finch, Gibson, Peacock, and Fluharty, 1949). From this curve the percentage utilization of the iron injected, which is normally over $90 \%$, and the half-time for iron utilization (normal $=2.7 \pm 0.66$ days) can be found. The 'marrow index' proposed by Joske et al. (1956) as a measure of the net functional activity of the marrow in erythropoiesis has been calculated from the formula:

$$
\text { Marrow index }=\frac{\text { percentage utilization }{ }^{59} \mathrm{Fe}}{\mathrm{T} \frac{1}{2} \mathrm{Fe}}
$$

With one exception, iron utilization was impaired, the mean being $66.7 \pm 13.6 \%$. The exception was Case 13 which utilized $90 \%$ of the injected dose despite a reduced uptake of iron-59 by the lumbar spine. The mean $\mathrm{T}_{2} \mathrm{Fe}$ for Cases 1 to 13 was 2.62 土 0.59 days, which is not significantly different from normal, suggesting that there is a normal rate of maturation and release of the red cells. The mean marrow index in this series was $26.5 \pm 8 \cdot 1$, which is significantly reduced.

The 'index of marrow activity' proposed by Chaplin and Mollison (1953) has also been calculated. This is equal to:

$\frac{\text { Observed haematocrit }}{\text { Normal haematocrit }} \times \frac{\text { Normal red cell survival }}{\text { Observed red cell survival }}$ and gives as a fraction of the normal the rate of red cell production required to maintain a steady packed cell volume. The value obtained for those cases without significant haemolysis $(0.80 \pm 0.21)$ was significantly less than that obtained for the cases with accelerated red cell destruction $(1.82 \pm 0.46)$ with $t=4.31$ and $P<0.01$.

LUMBAR SURFACE COUNTING The normal curve obtained by plotting the serial counts for iron-59 activity over the lumbar spine is shown in Fig. 1A. In five cases no activity could be demonstrated, in seven cases the activity was depressed, and in only one was a normal curve obtained. The activity expressed in these curves depends on three factors: The geometry of the marrow space, which is approximately constant between subject and subject; the unit activity of the marrow within the space, which is the main variable; and the total marrow volume which determines the fraction of the active iron presented to the marrow. This last factor leads to a reduction in the height of the uptake curve with expansion of the marrow volume, as in polycythaemia vera. At present a satisfactory method of correcting for the effect of variable marrow volume is lacking but it is probable that the marrow volume is reduced in the cases studied here and the curves underestimate the depression in activity.

SPLENIC SURFACE COUNTING Three distinct patterns were observed in surface counting for iron-59 over the spleen.

Type 1 showed maximal activity on the first day after injection and thereafter the activity declined rapidly until five to seven days later. This is shown in Fig. 2B, which illustrates the similarity of this curve to that found by counting over normal marrow, as in Fig. 1A. Five cases showed this pattern.

Type 2 showed a continual smooth rise in activity as in curve $A$ in Fig. 2A. The maxımum height was 


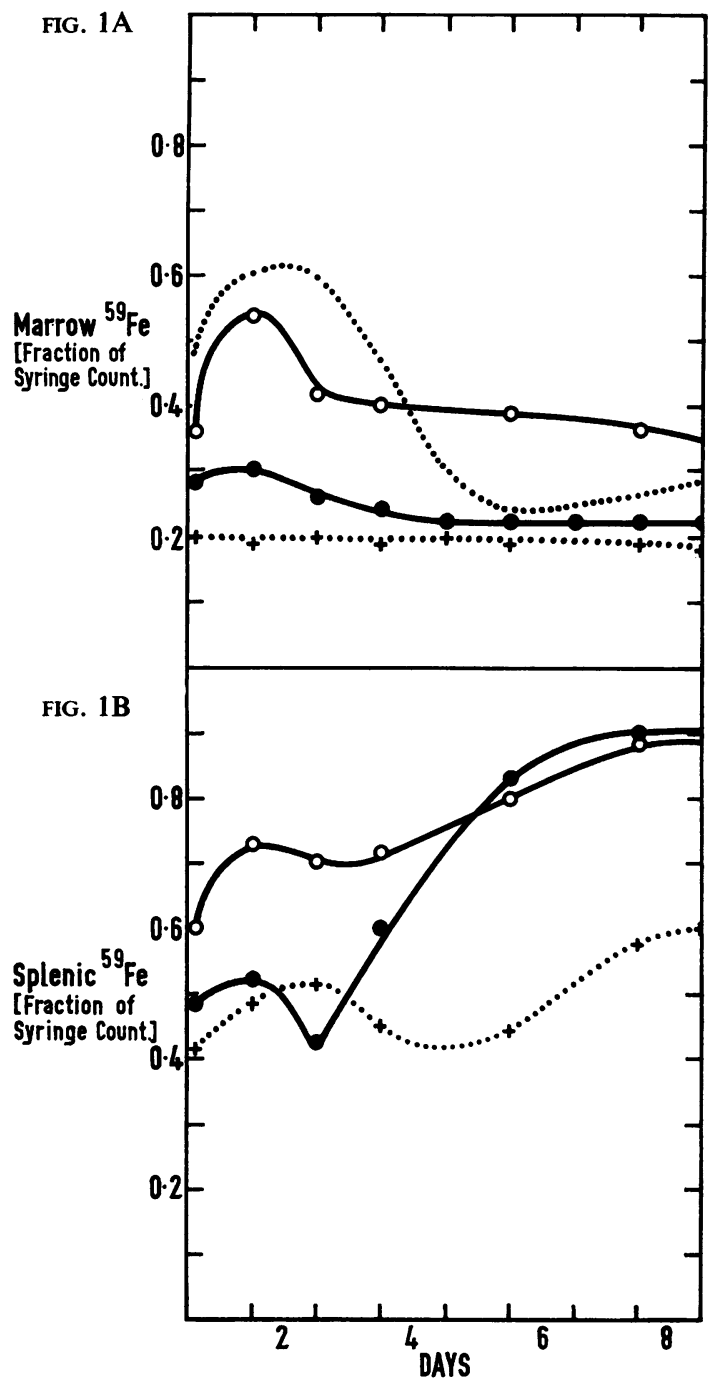

FIG. 1A. Graph of marrow iron-59 activity plotted against time. Case $1(\bullet-\bullet-\bullet)$ and Case 10 ( $1-0)$ illustrate depressed marrow activity and no activity is detectable in Case $2(+\cdots+\cdots+)$.

FIG. 1B. Graph of the splenic iron-59 activity plotted against time, showing examples of the type 3 pattern. Case $10(+\cdots \cdots+)$, Case $11(\bullet-\bullet)$, and Case $12(0-0)$.

reached between the fourth and eighth days and was followed by a sustained high plateau of activity. Four cases showed this pattern.

Type 3 showed a biphasic curve with an initial peak on the first day, followed after a shallow trough by a further rise, usually exceeding the first.

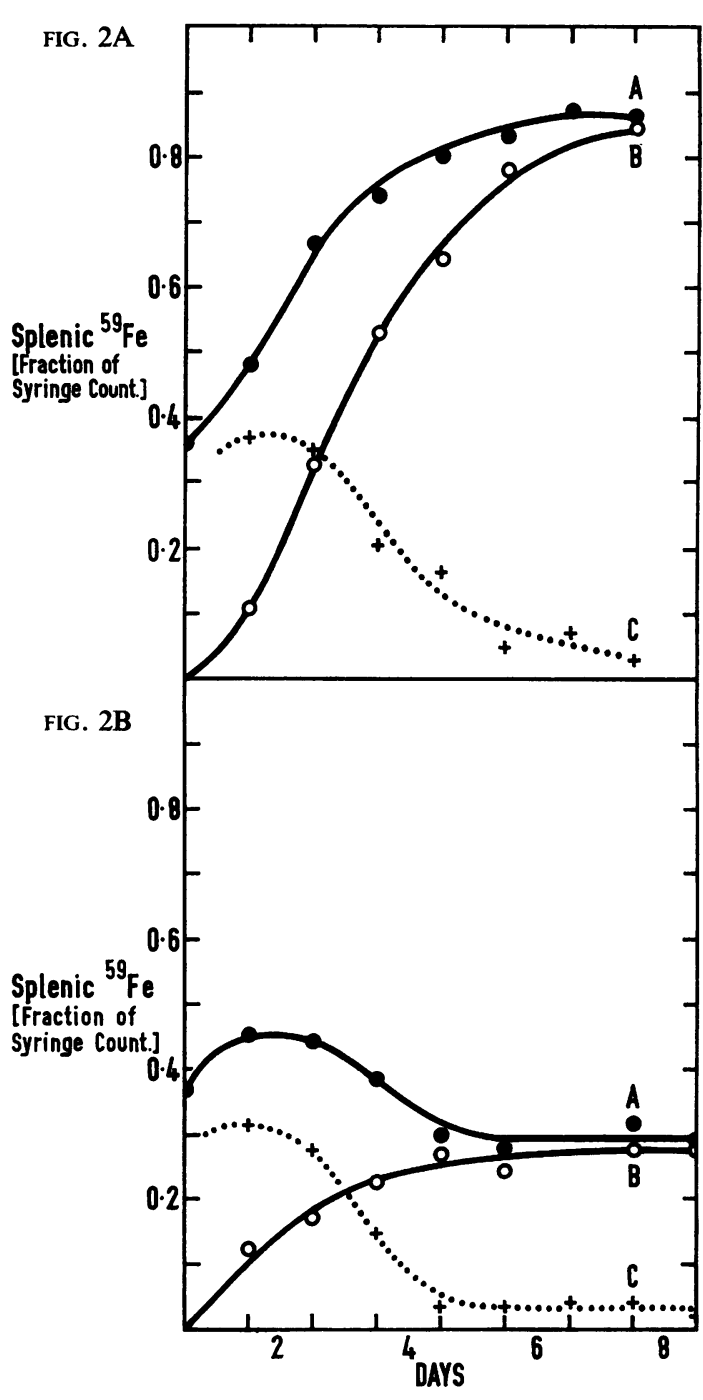


time, showing the type 2 pattern. Observed activity $A D$ $(\bullet-\bullet)$, calculated blood activity in the organ $B$ ․․․ $(\mathrm{O}-\mathrm{O})$, and the difference between the activities $C N$ $(+\cdots++)$.

FIG. 2B. Graph of splenic iron-59 activity plotted against time to illustrate the type 1 pattern (symbols as for Fig. 2A).

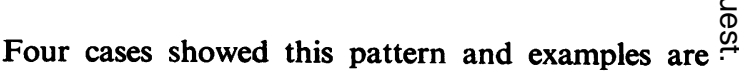
shown in Fig. 1B.

The type 1 and type 2 curves are shown in Figs. 2B and 2A, together with the estimated curves for $\stackrel{\square}{\mathscr{Q}}$ the activity of the blood in circulation through the $\stackrel{\mathbb{Q}}{\Omega}$ organ. The differences between the observed and the 
calculated curves are also plotted to give patterns which strongly resemble the normal iron uptake and release curves of bone marrow. These reflect the passage of iron through the splenic erythropoietic tissue and provide the principal component of the type 1 curve. In the type 2 curve the most prominent component is due to the circulating iron activity, while both components are distinguishable in the type 3 curve.

HEPATIC SURFACE COUNTING Changes in the iron-59 surface counts over the liver seldom gave clear evidence of intrahepatic erythropoiesis, no doubt due to the relative sparseness of the haemopoietic elements in this organ in most cases. Cases 3 and 13, however, showed a suggestive rise and fall in the counting rates, but this was of much lower magnitude than was found over the spleen in the type 1 pattern.

THIGH SURFACE COUNTING This was performed over the lower third of the thigh to detect the presence of marrow extension into the distal femur. This was demonstrated in Case 12 despite the absence of any demonstrable activity in the lumbar spine.

\section{DISCUSSION}

The anaemia of primary myeloid metaplasia thus appears to depend on impaired marrow activity and in some cases on accelerated red cell destruction. The shortened red cell life was demonstrated in the cases described by Weinstein and LeRoy (1953), Nathan and Berlin (1959), and Desforges, Ross, and Moloney (1960), but in the longer series of Fudenberg and Mahoney (1958) the incidence of significant haemolysis was closer to that found here. It is probable that the later in the course of the disease the investigation is made, the greater the likelihood of finding a shortened red cell life. Fudenberg and Mahoney (1958) have produced evidence from the survival times of red cells cross-transfused between normal subjects and patients with myeloid metaplasia that both intra- and extracorpuscular factors may be responsible for the haemolytic tendency; it is clear from Case 2 of this series that in certain cases at least the extracorpuscular factors may be predominant. In those cases in which significant organic uptake of chromium-51 accompanied erythrocyte destruction, the spleen, while showing the most marked accumulation of the isotope, was not involved in isolation. The appreciable degree of accumulation in the liver demonstrates that there is an extrasplenic element, which is suggestive of a metabolic defect in the red cells (Harris, McAlister, and Prankerd, 1957). This would account for the variable success of splenectomy in alleviating the premature destruction of red cells in this condition.

Following the description of cases under the title of 'agnogenic myeloid metaplasia' by Jackson et al. (1940), it was suggested that a possible explanation of the extramedullary haemopoiesis was that it arose in compensation for haemolysis. Thus, Claman and Collier (1952) described the case of a young adult with an acute haemolytic anaemia, in whom wellmarked haemopoiesis was demonstrable in the spleen. They concluded that 'the diagnosis of agnogenic myeloid metaplasia is rarely, if ever, tenable. At best it is a misnomer.' It is clear, however, from Case 1 that myeloid metaplasia may be demonstrated long before red cell destruction is significantly accelerated, and there are no grounds for supposing that haemolysis played any part in initiating the metaplastic process.

The depression of marrow activity commonly found in this condition is reflected in the impaired iron utilization, and in the low values obtained for the marrow index (Joske) and the index of marrow activity in this series. None of these patients, however, was examined while in the polycythaemic state which may accompany the condition. There was also failure of the erythropoietic tissue to respond adequately to the additional demands imposed by a shortened red cell life. It has been shown by Crosby and Akeroyd (1952) that under conditions of longstanding haemolysis the normal bone marrow can compensate for a red cell life as low as $\mathbf{1 5}$ days, with a rate of haemoglobin production about seven times the normal. In Cases 2, 8, and 10 the mean red cell life was between $\mathbf{4 0}$ and 50 days but all three patients were anaemic, and of the five with haemolysis the greatest response found was an increase of red cell production to 2.63 times normal.

The view has been frequently expressed that myeloid metaplasia arises in compensation for the loss of bone marrow activity resulting from marrow sclerosis or atrophy (Donhauser, 1908; Stephens, and Bredeck, 1933; Chapman, 1933; Wolf, 1932; Jordan and Scott, 1941; Leonard, Israels, and Wilkinson, 1957). In Case 2, the only detectable source of red cell production was the spleen, and the 'marrow' activity, as shown by both indices, was higher than normal. Nevertheless, the spleen was not greatly enlarged, and it is clear that the massive splenomegaly frequently encountered in these cases is greatly in excess of that required to accommodate a compensatory volume of haemopoietic cells. Conversely, the limited response to the additional requirements imposed by haemolysis does not seem to depend on spatial restriction, even in the presence of sclerotic obliteration of the marrow cavities, since anaemia may arise before the considerable potential for splenic enlargement is exhausted. It is 
also apparent from Case 5 that the myeloid metaplasia demonstrated by biopsy preceded significant bone marrow impairment; the iron-59 surface counting curve for the lumbar spine was normal, and since the marrow sclerosis in this condition usually proceeds centrifugally it is unlikely that marrow obliteration had advanced far in this case.

The leucoerythroblastosis shown by many patients with this condition has been ascribed to the extramedullary sites lacking the normal regulatory mechanisms for cellular release (Wintrobe, 1951; Leonard et al., 1957; Hayhoe and Whitby, 1955). However, the removal of the most active site of metaplastic haemopoiesis by splenectomy is frequently followed by the persistence of immature cells in the blood, as shown by the cases of Green, Conley, Ashburn, and Peters (1953). Neither the release phase of the splenic iron-59 curves nor the normal half-time for iron utilization suggested premature release of haemoglobinized cells.

With regard to the megakaryocytosis found in extramedullary sites in this condition, the view has been expressed that it contributes little to the appearance of platelets in the blood stream (Schwarz, 1954). Such doubts do not appear to apply to the erythropoietic elements, since the pattern of iron uptake and release over the spleen corresponds closely to that found over normal bone marrow in those cases with type 1 curves. These have also been described by Lawrence, Berlin, and Huff (1953) and by Schwartz, Tendler, Sharney, and Wasserman (1958). Curves similar to the type 2 pattern have been described by Huff, Elmlinger, Garcia, Oda, Cockrell, and Lawrence (1951), Schwartz et al. (1958), and Desforges et al. (1960), and have been ascribed to the reaccumulation of iron-59 containing cells in the spleen either immediately after their production or after release into the blood stream. However, in the present series, it has been shown that such a curve may be present without a reduction in red cell life, and that it arises principally from the activity of blood circulating through the organ.

The pathogenesis of primary myeloid metaplasia is still controversial. The present findings are consistent with the hypothesis put forward by Vaughan and Harrison (1939) that cells of mesenchymal origin are affected by a stimulus to proliferation, the differing patterns resulting from the degree to which the various cell lines are affected. This leads to haemopoietic cells, reticulum cells, and fibroblasts proliferating not only in the marrow cavities but in extramedullary sites as well. This would appear to be accompanied by a lessening of the responsiveness of the erythropoietic series to other stimuli, and it may be that in the later stages a competitive process limits the erythropoietic cell mass in favour of the fibroblast.

It remains to consider the value of radio-isotope $\stackrel{\vec{P}}{\rightarrow}$ studies in the management of these cases. First, they are useful in the detection of haemolysis, since the $\frac{\bar{\sigma}}{\bar{D}}$ usual clinical tests may fail in the absence of $a$ hyperactive marrow. Secondly, there appears to be a $\supseteq$ place for splenectomy in this condition, especially is in the presence of severe haemolysis with a high $\overrightarrow{0}$ transfusion requirement (Cartwright, Finch, Loeb, $\vec{\overrightarrow{ }}$ Moore, Singer, and Dameshek, 1955) and surface $\omega_{\mathscr{N}}$ counting over the spleen provides some evidence of 긍 chromium-51 accumulation in this organ, which? may be compared with other sites. In addition, $\vec{A}$ Hickling (1937) has drawn attention to the hazard of removing the spleen when it is a major source of 0 blood formation, and, although the basis for his con- 0 tentions has been criticized (Green et al., 1953), it remains true that some cases are indeed very depen- $\vec{z}$ dent on the extramedullary sites for haemopoiesis and in these splenectomy would be ill advised. Isotope studies provide useful information on the residual activity of the bone marrow and assist in assessing the dependence of the subject on the meta- $\overrightarrow{\mathscr{\theta}}$ plastic sites. Lastly, there is a small group of cases in which biopsy of liver, spleen, or bone is inadvisable owing to a haemorrhagic tendency, and in these isotope techniques may offer an alternative method of diagnosis.

My thanks are due to Professor M. L. Rosenheim for advice, to Dr. J. F. Stokes for his continued interest and encouragement, and to Dr. T. A. J. Prankerd for his supervision and instruction. I am also indebted to Mr. Aster, of the Department of Medical Illustration of University College Hospital Medical School, for preparing the diagrams.

\section{SUMMARY}

A series of patients with primary myeloid metaplasia has been investigated by radio-isotope techniques using chromium-51 and iron-59 to assess red cell $\rightarrow$ survival, iron utilization, and the patterns of the surface counts over various organs.

Bone marrow activity assessed by the counting for iron-59 over the lumbar spine was usually depressed and iron utilization was usually impaired. Severe anaemia in one subject arose from reduction in erythropoiesis alone.

Red cell destruction was accelerated to a significant degree in five of the 14 patients and was shown to develop as a late event after the onset of the 7 condition in one further case. The erythropoietic response to the haemolytic process was shown to be subnormal.

Iron-59 counting over the spleen showed a cycle of 
iron uptake and release closely corresponding to the pattern of normal marrow in some cases. In other cases, the iron- 59 activity of the circulating blood was prominently reflected in the surface counts and a method of analysing such patterns is given. Certain cases show a marked dependence on the extramedullary sites of blood formation.

Within the limits of these investigations, the extramedullary erythropoietic cycle has not been shown to differ significantly from normal, and in one instance it was possible to show that the red cells produced responded in the same degree as normal cells to an extracorpuscular haemolytic process.

The spleen was not found to be the isolated site of red cell destruction in any of the present cases, although it might be the most active organ in this respect.

The value of this type of investigation in the management and diagnosis of this condition has been discussed.

\section{REFERENCES}

Bailey, I. S., and Prankerd, T. A. J. (1958). Brit. J. Haemat., 4, 150. Block, M., and Jacobson, L. O. (1950). J. Amer. med. Ass., 143, 1390. Bowdler, A. J., and Prankerd, T. A. J. (1961). Brit. med. J., 1, 1352. Cartwright, G. E., Finch, C. A., Loeb, V., Moore, C. V., Singer, K., and Dameshek, W. (1955). Blood, 10, 550.

Chaplin, H., Jr., and Mollison, P. L. (1953). Clin. Sci., 12, 351.

Chapman, E. M. (1933). Amer. J. med. Sci., 185, 171.

Claman, M. A., and Collier, W. J. (1952). A.M.A. Arch. intern. Med., $89,431$.

Collins, D. C. (1932). Amer. J. Path., 8, 97.

Crosby, W. H., and Akeroyd, J. H. (1952). Amer. J. Med., 13, 273.

Dameshek, W. (1951). Blood, 6, 372.

Desforges, J. F., Ross, J. D., and Moloney, W. C. (1960). Amer. J. Med., 28, 69.

Donhauser, J. L. (1908). J. exp. Med., 10, 559.

Finch, C. A., Gibson, J. G., Peacock, W. C., and Fluharty, R. G. (1949). Blood, 4, 905.

Fudenberg, H., and Mahoney, J. P. (1958). Proc. 6th int. Congr. int. Soc. Hematology, Boston, 1956, p. 367. Grune and Stratton, New York.

Green, T. W., Conley, C. L., Ashburn, L. L., and Peters, H. R. (1953). New Engl. J. Med., 248, 211.

Harris, I. M., McAlister, J. M., and Prankerd, T. A. J. (1957). Clin. Sci., 16, 223.

and Singh, M. M. (1957). Ibid, 16, 633.

Hayhoe, F. G. J., and Whitby, L. (1955). Quart. J. Med., 24, 365.

Heller, E. L., Lewisohn, M. G., and Palin, W. E. (1947). Amer. J. Path., 23, 327.

Hickling, R. A. (1937). Quart. J. Med., n.s. 6, 253.

Huff, R. L., Elmlinger, P. J., Garcia, J. F., Oda, J. M., Cockrell, M. C., and Lawrence, J. H. (1951). J. clin. Invest., 30, 1512.

Hutt, M. S. R., Pinniger, J. L., and Wetherley-Mein, G. (1953). Blood, 8, 295.

Jackson, H. Jr., Parker, F. Jr., and Lemon, H. M. (1940). New Engl. J. Med., 222, 985.

Jordan, H. E., and Scott, J. K. (1941). Arch. Path. (Chicago), 32, 895.

Joske, R. A., McAlister, J. M., and Prankerd, T. A. J. (1956). Clin. Sci., 15, 511.

Lawrence, J. H., Berlin, N. I., and Huff, R. L. (1953). Medicine (Baltimore), 32, 323.

Leonard, B. J., Israels, M. C. G., and Wilkinson, J. F. (1957). Quart. J. Med., n.s. 26, 131.

Nathan, D. G., and Berlin, N. I. (1959). Blood, 14, 668.

Reich, C., and Rumsey, W. (1942). J. Amer. med. Ass., 118, 1200.

Schwarz, E. (1954). Amer. J. clin. Path., 24, 629.
Schwartz, L., Tendler, D., Sharney, L., and Wasserman, L. (1958). Proc. 6th Int. Congr. Int. Soc. Hematology, Boston, 1956, p. 361. Grune and Stratton, New York.

Stephens, D. J., and Bredeck, J. F. (1933). Ann. intern. Med., 6, 1087. Vaughan, J. M., and Harrison, C. V. (1939). J. Path. Bact., 48, 339. Weinstein, I. M., and LeRoy, G. V. (1953). J. Lab. clin. Med., 42, 368.

Wintrobe, M. M.(1951). Clinical Hematology, 3rd ed. Lea and Febiger, Philadelphia.

Wolf, C. (1932). Beitr. path. Anat., 89, 151.

\section{APPENDIX}

It was necessary in this investigation to derive an expression for the iron-59 activity of an organ, with special reference to the spleen, as distinguished from that of the blood flowing through it. In order to allow for possible changes in the blood content of the organ with time, the correction was based on the ratios of the two isotopes, chromium-51 and iron-59, as measured in the blood, and the relative counting rates of the isotopes over the organ concerned. Cases in which there was a demonstrable accumulation of chromium-51 in the organ were excluded from this method.

The isotopes within an organ will be partially screened by the thickness of tissue lying between them and the surface counter. Owing to the lower energy of the gamma radiation of chromium-51, the attenuating (Compton) effect of the tissues will be greater for this isotope than for iron-59. Hence the recorded counting rates will be more greatly reduced. The screening effect will also differ between subjects and must be calculated for cases individually.

For screened irradiation of a given energy, $I=k . I_{\text {o, }}$, where $I$ is the emergent radiation, $I_{o}$ is the energy of the source, and $\mathbf{k}$ is a constant dependent on the energy of the radiation, the partial absorption coefficient of the screening material and the thickness of the screen. In the case of an organ such as the spleen, the value of $k$ will differ for the two isotopes but for each isotope will be constant over limited periods for a given subject. Thus: $\quad \mathbf{S}_{\mathrm{fe}}^{\prime}=\mathrm{k}_{\mathrm{fe}} \cdot \mathbf{S}_{\mathrm{te}}$ and $\mathbf{S}_{\mathrm{cr}}^{\prime}=\mathbf{k}_{\mathrm{cr}} \cdot \mathbf{S}_{\mathrm{cr}}$

where $S^{\prime}{ }_{\text {fe }}$ and $S_{\text {cr }}^{\prime}$ are the activities of the isotopes recorded by surface counting, $S_{\mathrm{fe}}$ and $S_{\mathrm{cr}}$ are the source activities of the blood within the organ, and $k_{f e}$ and $\mathrm{k}_{\mathrm{er}}$ are constants dependent on the thickness and density of the screening tissues.

The source intensity will be proportional to the activities of the isotopes in the blood given by well counting, and thus:

$$
\begin{aligned}
S_{\mathrm{fe}} & =\mathbf{k}_{\mathrm{re}}^{\prime} \cdot \mathbf{W}_{\mathrm{fe}} \\
\text { and } \mathrm{S}_{\mathrm{cr}} & =\mathbf{k}_{\mathrm{cr}}^{\prime} \cdot \mathbf{W}_{\mathrm{cr}},
\end{aligned}
$$

where $W_{f e}$ and $W_{c r}$ are the activities recorded on well counting, and $\mathrm{k}^{\prime} \mathrm{e}$ and $\mathrm{k}^{\prime}{ }_{\mathrm{cr}}$ are constants depending on the apparatus and the geometry of the organ. It follows therefore that:

$$
\begin{gathered}
S_{\mathrm{fe}}^{\prime}=\mathrm{k}_{\mathrm{fe}} \cdot \mathbf{k}_{\mathrm{fe}}^{\prime} \cdot \mathbf{W}_{\mathrm{fe}} \\
\text { and } \mathbf{S}_{\mathrm{cr}}^{\prime}=\mathbf{k}_{\mathrm{cr}} \cdot \mathbf{k}_{\mathrm{cr}}^{\prime} \cdot \mathbf{W}_{\mathrm{cr}} \\
\text { Thus, if } \mathbf{k}^{\prime \prime}=\frac{\mathbf{k}_{\mathrm{fe}} \cdot \mathbf{k}_{\mathrm{fe}}^{\prime},}{\mathbf{k}_{\mathrm{cr}} \cdot \mathbf{k}_{\mathrm{cr}}^{\prime}} \text { then } \frac{S_{\mathrm{te}}^{\prime}}{\mathbf{S}_{\mathrm{cr}}^{\prime}}=\mathbf{k}^{\prime \prime} \cdot \frac{W_{\mathrm{fe}}}{W_{\mathrm{cr}}}
\end{gathered}
$$




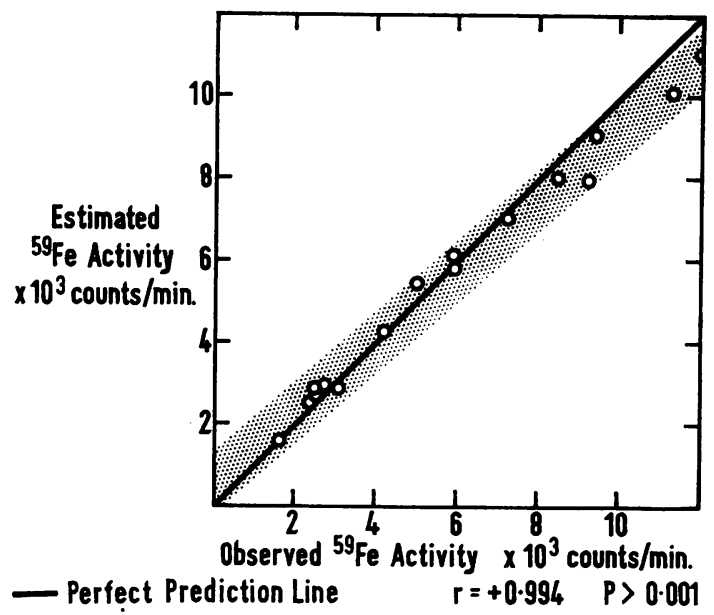

FIG. 3. Graph of estimated iron-59 activity of a model spleen against measured activity. The shaded area lies between the $95 \%$ confidence limits of the points shown. it is possible to determine $S_{\text {fe, }}^{\prime} S_{\text {er }}^{\prime}, W_{\text {fe, }}$, and $W_{\text {er }}$ from the initial counting over the organ after allowing time for the injected blood to mix with the circulation, and from the blood activity of the isotopes at this time. Therefore $\mathrm{k}^{\prime \prime}$ can be found, and for subsequent days the activity of the iron-59 in the blood within the organ calculated. This is corrected as usual for decay from the day of injection and expressed as a fraction of the syringe count.

To test the reliability of the method in predicting the organ activity of one isotope from the activity of the second and the blood values, observations were made over a model spleen, consisting of a wax shell made as a cast of an enlarged spleen removed at necropsy and having a volume of about $1,600 \mathrm{ml}$. The model was filled with water and the two isotopes were added, the concentrations being varied independently. The surface recordable activity of the model and the activities of the isotopes it contained were measured, and the iron-59 activity of the model was predicted by the method outlined. The results are plotted in Fig. 3 and the correlation between the measured and the predicted activity was considered satisfactory. 